\title{
Protective effect of total flavonoids from boxthorn leaf against UVB irradiation-induced skin injury
}

\author{
Qing Yu ${ }^{1 *}$, Ying Shen ${ }^{2}$, Yadan Gan ${ }^{1}$, Liang Zheng ${ }^{3}$ \\ ${ }^{1}$ Dermatological Department, YuYao People's Hospital, ${ }^{2}$ Dermatological Department, The Second Affiliated Hospital of Zhejiang \\ University School of Medicine, ${ }^{3}$ Derpartment of Pharmacy, YuYao People's Hospital, Zhejiang, China
}

${ }^{*}$ For correspondence: Email: j92Ihe@163.com

Sent for review: 8 November 2018

Revised accepted: 23 August 2019

\begin{abstract}
Purpose: To investigate the protective effect of total flavonoids from boxthorn leaf against skin injury induced by UVB irradiation, and to elucidate the underlying mechanism of action.

Method: Healthy female mice $(n=100)$ were randomly divided into four groups: normal control group, UV negative control group, cream base group, and boxthorn leaf total flavonoid (BLTF) group, with 25 mice in each group. The mice in each group were irradiated with ultraviolet $B$ (UVB) irradiation instrument for $1.5 \mathrm{~h}$ daily for 3 weeks. Mice in the cream base group were smeared with cream base on their backs, while mice in BLTF group were smeared with $15 \mathrm{mg} / \mathrm{g}$ boxthorn BLTF cream. The control and negative control group mice were not treated. Changes in superoxide dismutase (SOD), malondialdehyde (MDA) and glutathione peroxidase (GSH-PX) levels were determined using standard methods.

Results: Compared to the negative control group, the levels of SOD and GSH-Px in the control group and BLTF were significantly elevated, while MDA levels declined significantly $(p<0.05)$. Although higher GSH-Px and SOD levels, and lower MDA were seen in the cream base group than in negative control group, these indices were comparable for the two groups $(p>0.05)$.

Conclusion: The total flavonoids of boxthorn leaves improve resistance to UVB-induced skin damage by regulating SOD, MDA and GSH-Px levels in the skin of mice. Thus, they exert protective effects on the skin.
\end{abstract}

Keywords: Boxthorn leaf total flavonoids, Ultraviolet B, Skin injury, Protection, Mechanism

This is an Open Access article that uses a fund-ing model which does not charge readers or their institutions for access and distributed under the terms of the Creative Commons Attribution License (http://creativecommons.org/licenses/by/4.0) and the Budapest Open Access Initiative (http://www.budapestopenaccessinitiative.org/read), which permit unrestricted use, distribution, and reproduction in any medium, provided the original work is properly credited.

Tropical Journal of Pharmaceutical Research is indexed by Science Citation Index (SciSearch), Scopus, International Pharmaceutical Abstract, Chemical Abstracts, Embase, Index Copernicus, EBSCO, African Index Medicus, JournalSeek, Journal Citation Reports/Science Edition, Directory of Open Access Journals (DOAJ), African Journal Online, Bioline International, Open-J-Gate and Pharmacy Abstracts

\section{INTRODUCTION}

The boxthorn is a plant grown in nutrient-rich, neutral or slightly acidic light soil. There are 8 varieties which include Lycium ruthenicum and Lycium barbarum. Sun Simiao, a famous medical scientist in Tang Dynasty wrote in Qianjinyifang that Lycium barbarum is true in ganzhou and thick in leaves [1]. The boxthorn comprises the tender stem and leaves of eggplant or Lycium barbarum. The boxthorn leaves are rich in betaine, rutin, carotene, riboflavin and other trace elements and amino acids, which have been shown to prevent arteriosclerosis and aging, and to promote blood circulation [2]. Flavonoids are natural compounds with the structure of 2phenylchromone, which bind to sugar in plants to 
form glycosides. They have good therapeutic effects against diabetes mellitus and hypertension, and they also act as antioxidants in organisms $[3,4]$. Cells produce a series of anion free radicals in the process of metabolism. Flavonoids inhibit ROS generation by inhibiting the activities of certain enzymes, thereby protecting the antioxidant defense system of the organism [5].

Ultraviolet $B$ (UVB) is an electromagnetic wave with wavelength range of $280-320 \mathrm{~nm}$. Excessive ultraviolet radiation causes great harm to the human body, especially the skin. A large dose of UVB radiation can reduce the activities of antioxidant enzymes and release a large amount of inflammatory factors, resulting in erythema, vesicles, and even festering and breakage of the skin surface [6].

In this study, the protective effect of total flavonoids from boxthorn leaves against skin damage induced by UVB irradiation was investigated, and the mechanism involved was studied.

\section{EXPERIMENTAL}

\section{Animals}

A total of 100 healthy female mice (mean weight $=20.35 \pm 2.12 \mathrm{~g}$ ) were supplied by Shanghai Ruitaimosi Biotechnology Co. Ltd [production license: SCXK (Shanghai) 2016-0001]. The mice were kept in a laboratory at a temperature of 22 $\pm 3^{\circ} \mathrm{C}$ and humidity of $58 \pm 12 \%$.

This study received approval from the Animal Ethical Committee of Dermatological Department of our institution (approval no. 201814796), and it was conducted in line with guidelines of "Principles of Laboratory Animal Care" $(\mathrm{NIH}$ publication of 1985) [7].

\section{Instruments and reagents}

The main instruments and reagents used, and their suppliers (in brackets) were UVB irradiator (Shanghai Taoyi Industrial Co. Ltd, model: ST513); Animal shaving apparatus (Ningbo Aikelipu Electric Appliances Co. Ltd); Centrifuge (Shanghai Luxiang instrument Co. Ltd, model: TG18.5); Vaseline (Nanchang Baiyun Pharmaceutical Co., Ltd., specifications: $500 \mathrm{~g}$ ); superoxide dismutase and glutathione peroxidase assay kits (Shanghai Jining Biotechnology Co. Ltd), and malondialdehyde test kit (Shanghai Hengyuan Biotechnology Co. Ltd). Boxthorn leaf total flavonoid cream was prepared fresh prior to use.

\section{Animal grouing and treatment}

All mice were anesthetized with intraperitoneal injection of 1 to $2 \mathrm{mg} / \mathrm{kg}$ ketamine hydrochloride, and their back hair was shaved after successful anesthesia. The mice were randomly divided into four groups: normal control group, UV negative control group, cream base group, and BLTF, using the random digital table method, with 25 mice in each group. Except for the control group, the mice in each group were irradiated with UVB irradiation instrument for $1.5 \mathrm{~h}$ daily for 3 weeks. When erythema or fester appeared on the back skin of the mice, it was used as an indication that the model was successfully established. Mice in the cream base group were smeared with cream base on the back, while mice in the BLTF group were smeared with $15 \mathrm{mg} / \mathrm{g}$ BLTF cream. Mice in the control and negative control groups were untreated.

\section{Treatment indices}

\section{Histology}

All mice were weighed before the experiment, and at 7, 14 and 21 days, and weight changes in the mice in each group were compared. After 3 weeks, changes in the back skin of all mice were recorded. Following sacrifice on day 21, back skin samples were taken from the mice and processed histologically for light microscopy using hematoxylin and eosin ( $\mathrm{H} \& \mathrm{E})$ staining.

\section{Biochemical assays}

Mice back skin tissue was cut into smaller bits, homogenized and centrifuged. The supernatant was employed for determination of SOD, GSHPx and MDA levels, using SOD, GSH-PX and MDA test kits, respectively.

\section{Statistical analysis}

Data are expressed as mean \pm standard deviation (SD). Independent sample $t$-test was employed for group comparisons. Counting data are presented as $\mathrm{n}(\%)$, and comparison between groups was done with $x^{2}$ test. All statistical analyses were carried out with SPSS 21 software. Statistical significance was fixed at $p$ $<0.05$.

\section{RESULTS}

\section{Body weight changes in mice}

Table 1 shows that before the experiment, body weight was comparable amongst the 3 mice groups $(p>0.05)$. On the $14^{\text {th }}$ and the $21^{\text {st }}$ days, 
the body weight of mice in the cream base and the negative control groups decreased significantly, when compared with control. However, body weight was comparable between BLTF mice and control mice $(p>0.05)$.

\section{Skin appearance of mice}

The back skin of mice in negative control group was red and festering with injuries. The back skin of mice in the cream base group was redder, relative to control mice. However, festering was lighter than was seen in negative control mice. There was only a slight wrinkle in the back skin of BLTF mice, which was similar to that of the control group. These results are shown in Figure 1.
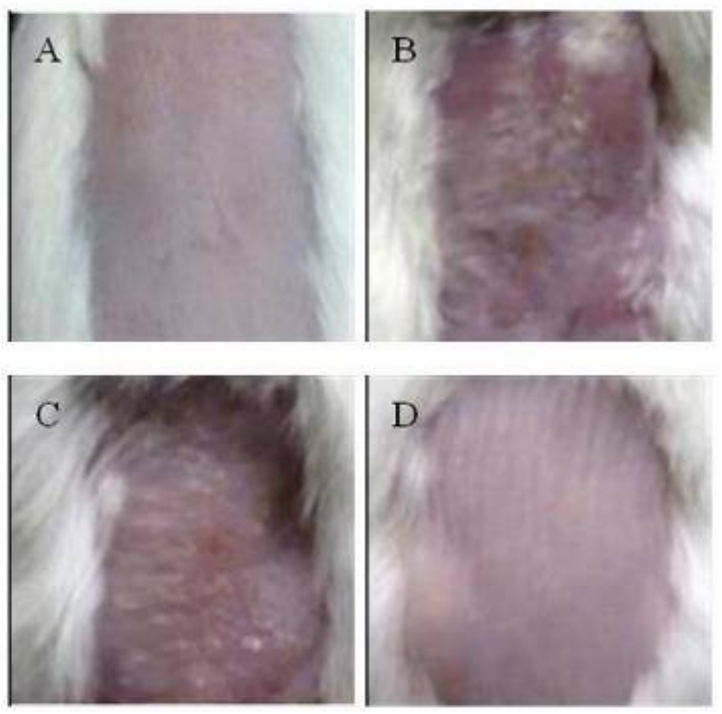

Figure 1: Comparative skin appearance of mice in the 4 groups. $A=$ Control group; $B=$ Negative control group; $\mathrm{C}=$ Cream base group; $\mathrm{D}=\mathrm{BLTF}$ group

\section{Skin tissue structure of the mice}

The skin epidermal layer of the control group was thin; the layering was clear, the mastoid process was obvious, and the fibrous tissues was arranged closely. In the negative control group of mice, there were thickened skin epidermal layer, uneven layering, increased distances between the mastoid processes, loose arrangement of fibrous tissue, and evidence of crimping and breaking of fibrous tissue. The skin epidermal structures of mice in the cream base and negative control groups were similar. In contrast, the skin epidermal layer of the BLTF group was similar to that of the control group. In the BLTF group, crimping and breaking of fibrous tissue were significantly reduced, when compared with the negative control group. These results are shown in Figure 2.
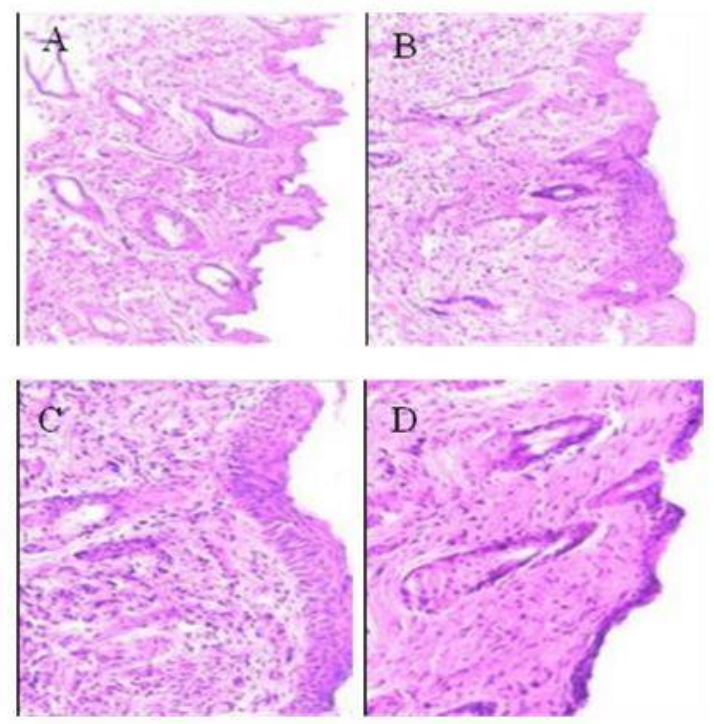

Figure 2: Comparative skin tissue structure among the 4 groups of mice. A: Control group; B: Negative control group; C: Cream base group, and D: BLTF group

\section{SOD, MDA and GSH-Px levels}

There were significant elevations in GSH-Px and SOD in the control group and BLTF group, while MDA level was markedly decreased $(p<0.05)$. In contrast, although higher GSH-Px and SOD levels, and lower MDA were seen in the cream base group than in negative control group, these indices were comparable between them $(p>$ 0.05). These results are shown in Table 2.

Table 1: Body weight changes over the experimental period (mean $\pm S D, n=25$ )

\begin{tabular}{lllll}
\hline Group & Before experiment & Day 7 & Day 14 & Day 21 \\
\hline Control & $20.58 \pm 0.93$ & $23.53 \pm 1.74$ & $27.43 \pm 2.58$ & $32.35 \pm 3.19$ \\
Negative control & $20.33 \pm 1.33$ & $22.05 \pm 1.92^{*}$ & $25.07 \pm 2.68^{*}$ & $27.05 \pm 2.61^{\text {*\# }}$ \\
Cream base & $21.25 \pm 2.14$ & $22.89 \pm 1.58$ & $24.52 \pm 2.43^{\text {*\# }}$ & $26.12 \pm 2.84^{\text {\#\# }}$ \\
BLTF & $20.93 \pm 2.17$ & $23.44 \pm 2.32$ & $26.34 \pm 2.62$ & $31.81 \pm 3.49$ \\
$F$ & 1.36 & 1.94 & 6.41 & 27.55 \\
$p$ & 0.261 & 0.128 & 0.001 & $<0.001$ \\
\hline
\end{tabular}

${ }^{*} P>0.05$, compared with the control group; $\# p>0.05$, compared with BLTF 
Table 2: SOD, MDA and GSH-Px levels of mice (mean \pm SD, $n=25$ )

\begin{tabular}{lccc}
\hline Group & SOD $(\mathbf{U} / \mathbf{m g})$ & MDA $(\mathbf{n m o l} / \mathbf{m g})$ & GSH-Px $(\mathbf{m g} / \mathbf{g})$ \\
\hline Control & $130.12 \pm 8.65^{*}$ & $1.33 \pm 0.32^{*}$ & $10.73 \pm 1.65^{*}$ \\
Negative control & $74.84 \pm 11.18$ & $3.11 \pm 0.92$ & $2.41 \pm 1.52$ \\
Cream base & $80.37 \pm 10.28$ & $2.88 \pm 0.93$ & $3.21 \pm 1.31$ \\
BLTF & $107.52 \pm 11.41^{*}$ & $1.52 \pm 0.33^{*}$ & $7.81 \pm 1.98^{*}$ \\
$F$ & 150.67 & 43.51 & 144.69 \\
$P$-value & $<0.001$ & $<0.001$ & $<0.001$ \\
\hline${ }^{*} P>0.05$, compared with negative control group &
\end{tabular}

\section{DISCUSSION}

Ultraviolet rays refer to radiation of electromagnetic waves at wavelength range of 10-400 nm. Based on differences in wavelength, ultraviolet rays can be divided into ultraviolet $A$ segment (UVA; wavelength 320 to $400 \mathrm{~nm}$ ); ultraviolet B segment (UVB; wavelength 280 to $320 \mathrm{~nm}$ ), and ultraviolet C segment (UVC; wavelength 100 to $280 \mathrm{~nm}$ ). The UVA and UVB are capable of reaching the earth through the ozone layer, thereby causing damage to human skin. The carcinogenicity of UVA is stronger than that of UVB, but the damage intensity of UVB to skin is much greater than that of UVA [8]. The current study was carried out to investigate the protective influence of boxthorn leaf total flavonoids against skin damage induced by UVB irradiation, and the mechanism involved.

Some studies have found that long-term exposure to UVB radiation causes changes in skin tissue structure. It has been reported that UVB irradiation blocks the growth of cells, and causes severe apoptosis, resulting in skin wrinkle, erythema, and even necrosis and festering $[9,10]$. The results of this study showed that in the negative control group, there were thickened skin epidermal layer, uneven layering, increased distances between the mastoid processes, loose arrangement of fibrous tissue, and evidence of crimping and breaking of fibrous tissue. There was similarity in skin epidermal structures of cream base mice and negative control mice. In contrast, skin epidermal layers of the BLTF group and control group were similar. There were less crimping and breaking of fibrous tissue in the BLTF than in the negative control group. These results indicate that the UVB radiation caused serious injury to the skin, and that boxthorn leaf total flavonoids protected the skin of mice from UVB-induced injury. It has been reported that UV exposure gradually decreases skin collagen content, and that UVB radiation produces a large amount of reactive oxygen species (ROS) which damage cells through lipid peroxidation [11].

Malondialdehyde (MDA) is a critical concomitant of lipid peroxidation, and it aggravates membrane damage. Therefore, the level of MDA can be used as an effective index of damage due to oxidative stress [12]. It has been found that the level of SOD in mice exposed to ultraviolet radiation for a long time is significantly decreased. Superoxide dismutase (SOD) is a physiological antioxidant enzyme which eliminates harmful oxygen free radicals generated during metabolism in organisms. Thus, SOD is beneficial in reducing body damage caused by oxidative stress [13, 14]. Glutathione peroxidase (GSH-Px) is distributed widely in organisms. The active center of $\mathrm{GSH}$ $P x$ is a selenocysteine which catalyzes the conversion of GSH to GSSG, and catalyzes the neutralization of hydrogen peroxide, thereby mitigating oxidative lesions to biomembranes $[15,16]$.

It was demonstrated in this study that GSH-Px and SOD levels in the control group and BLTF group were significantly elevated, while MDA level was significantly reduced. In contrast, although higher GSH-Px and SOD levels, and lower MDA were seen in the cream base group than in negative control group, these indices were comparable between them. These results suggest that the total flavonoids of boxthorn leaves enhance GSH-Px and SOD activities, and reduce skin MDA concentration in UVB-treated mice. Thus, the flavonoids have protective effect against UVB irradiation-induced skin damage.

\section{CONCLUSION}

The results obtained in this study show that the total flavonoids of boxthorn leaves reduce oxidative damage caused by $\mathrm{H}_{2} \mathrm{O}_{2}$, thereby protecting the integrity of the cell membrane. The total flavonoids protect the skin from UVBinduced damage by reducing MDA concentration and increasing GSH-Px and SOD levels.

\section{DECLARATIONS}

\section{Conflict of interest}

No conflict of interest is associated with this work. 


\section{Contribution of authors}

We declare that this work was done by the authors named in this article, and all liabilities pertaining to claims relating to the content of this article will be borne by them. All authors read and approved the manuscript for publication. Qing Yu conceived and designed the study. Qing Yu, Ying Shen, Yadan Gan and Liang Zheng collected and analyzed the data, while Qing Yu wrote the manuscript.

\section{Open Access}

This is an Open Access article that uses a funding model which does not charge readers or their institutions for access and distributed under the terms of the Creative Commons Attribution License (http://creativecommons.org/licenses/by/ 4.0) and the Budapest Open Access Initiative (http://www.budapestopenaccessinitiative.org/rea d), which permit unrestricted use, distribution, and reproduction in any medium, provided the original work is properly credited.

\section{REFERENCES}

1. Li JX, Fan XF, Liu XL, Zhang BX, Wang PJ. Advances in research on chemical constituents and their pharmacological effects. Food Safety Guide 2016; 24: 75.

2. Jatoi $M A$, Jurić $S$, Vidrih $R$, Vinceković $M$, Vuković $M$, Jemric $T$. The effects of postharvest application of lecithin to improve storage potential and quality of fresh goji (Lycium barbarum L.) berries. Food Chem 2017; 230: 241-249.

3. Chen $B H, L i T$, Chen JY, Gao XL, Wu CR. Adsorption and desorption properties of macroporous resins for total flavonoids from Oenotheralittaralis leaves. J Plant Res Environ 2016; 15(2): 11-15.

4. Chen GM, Wang $L$, Du $P$, Li ZP, Shen $H Y$. Polysaccharide from Ophiopogon japonicus protects against ultraviolet $B$ damage to the human dermal fibroblasts. Chin J Tissue Eng Res 2017; 21(32): 51835188.

5. Bazylko A, Parzonko A, Jeż W, Osińska E, Kiss AK. Inhibition of ROS production, photoprotection, and total phenolic, flavonoids and ascorbic acid content of fresh herb juice and extracts from the leaf and flowers of Tropaeolummajus. Ind Crops Prod 2014; 55(4): 19-24.

6. Wang ZC. Protective effects of Oleum Curcumae Wenchowensis on Skin Damage due to UVB. Chin J Radiol Med Prot 2016; 26(5): 533-535.

7. World Health Organization. Principles of laboratory animal care. WHO Chron 1985; 39:51-56.

8. Yan L, Huang DL, Ding ZH. Advances on the research of ultraviolet radiation-protective agents. Guangdong Med J 2017; 30(6): 989-991.

9. Gerhardt KE, Lampi MA, Greenberg BM. The effects of far-red light on plant growth and flavonoid accumulation in Brassica napus in the presence of ultraviolet $B$ irradiation. Photochem Photobiol 2018; 84(6): 14451454.

10. Li J, Li SZ, Feng WJ, Yuan W. In vitro Antioxidant and Free Radical Scavenging Activities of Total Flavonoids from the Leaves of Lycium ruthenicum Murr. Food Sci 2015; 31(13): 259-262.

11. Nomura $Y$, Kinjo M. Real-Time Monitoring of in vitro Transcriptional RNA by Using Fluorescence Correlation Spectroscopy. Chembiochem 2014; 5(12): 1701-1703.

12. Xu L, Islam F, Zhang WF, Awais Ghani M, Ali B. 5Aminolevulinic acid alleviates herbicide-induced physiological and ultrastructural changes in, Brassica napus. J Integr Agric 2018; 17(3): 579-592.

13. Martínez-Medina A, Fernandez I, Lok GB, Pozo MJ, Pieterse CM, Van Wees SC. Shifting from priming of salicylic acid- to jasmonic acid-regulated defences by Trichoderma protects tomato against the root knot nematode Meloidogyne incognita. New Phytol 2017; 213(3): 1363-1377.

14. Zheng $H$, Zhou $Q$, Du $Y$, Li $C, X u P T$, et al. The hypothalamus as the primary brain region of metabolic abnormalities in APP/PS1 transgenic mouse model of Alzheimer's disease. Biochim Biophys Acta 2018; 1864(1): 263-273.

15. Wang PF, Mu XP, Du JJ, Gao YG, Bai DH, et al. Flavonoid content and radical scavenging activity in fruits of Chinese dwarf cherry (Cerasus humilis) genotypes. J For Res 2017; 29(25): 1-9

16. Tingyang $Z$, Evan $P$, Davis G, Zuo L. Interplay between ROS and Antioxidants during Ischemia-Reperfusion Injuries in Cardiac and Skeletal Muscle. Int $\mathrm{J}$ Mol Sci 2018; 19(2): 417. 